\title{
Anti-arbitration injunctions: walking the tightrope
}

\author{
Richard Garnett*
}

\section{KEY REFERENCES}

- United Nations Convention on the Recognition and Enforcement of Foreign Arbitral Awards (New York, 10 June 1958)

- UNCITRAL Model Law on International Commercial Arbitration

(Vienna, 21 June 1985) with amendments adopted in 2006

- Arbitration Act 1996 (UK)

- Senior Courts Act 1981 (UK) s 37

- Minister of Finance Inc and 1 Malaysian Development Berhad v International Petroleum Investment Coy [2019] EWCA Civ 2080

- Sabbagh v Khoury [2019] EWCA Civ 1219

- Weissfisch v Julius [2006] EWCA Civ 218

- Carter Holt Harvey Ltd v Genesis Power Ltd [2006] NZHC 114

- Jaya Sudhir Jayaram v Nautical Supreme Sdn Bhd (2019) 7 CLJ 395

- Li v Rao 2019 BCCA 264

- Kraft Foods Group Brands Ltd v Bega Cheese Ltd [2018] FCA 549

\begin{abstract}
Anti-arbitration injunctions are a controversial issue in the field of international arbitration. While some commentators decry them as an interference with the autonomy and independence of arbitrators, English and other common law courts steadfastly refuse to renounce them entirely. By reference to the framework established in recent decisions of the English Court of Appeal, the article seeks to forge a middle path between making anti-arbitration injunctions available on a discretionary, case management basis and prohibiting them in all cases. An approach that respects both the rights of arbitrators to determine their own jurisdiction and the rights of courts to protect parties from abuse of the arbitral process is advocated.
\end{abstract}

* Richard Garnett, Professor of Law, Melbourne Law School, The University of Melbourne, Victoria, Australia; Consultant (international disputes), Corrs Chambers Westgarth. Email: r.garnett@unimelb.edu. au

(C) The Author(s) 2020. Published by Oxford University Press on behalf of the London Court of International Arbitration. All rights reserved. For permissions, please email: journals.permissions@oup.com 
A controversial topic in the field of international arbitration is the anti-arbitration injunction. An anti-arbitration injunction is an order that seeks to restrain a party (or sometimes an arbitral tribunal) from commencing or continuing an arbitration proceeding. Historically, such orders were only occasionally granted and received strong criticism from commentators because they were thought to infringe key instruments and principles of international arbitration law, such as the New York Convention on the Recognition and Enforcement of Foreign Arbitral Awards.

More recently, however, there have been signs of a resurgence of the remedy in common law jurisdictions, particularly in the case of concurrent proceedings in respect of the same subject matter between courts and arbitrators. The aim of this article is to assess the current status of the injunction and its desirability in international commercial disputes. Is the appropriate analysis to exclude anti-arbitration injunctions completely or adopt a liberal case management or forum non conveniens approach to their grant? Alternatively, should courts or legislatures seek to find a solution that walks the tightrope between the competing views?

\section{THE TRADITIONAL COMMON LAW POSITION}

While anti-arbitration injunctions have in theory been available in English law for over a century, in practice, they were rarely granted. Specifically, an applicant had to show that (i) the injunction would not cause injustice to the claimant in the arbitration and (ii) the continuation of the arbitration would be oppressive and vexatious or an abuse of process of the court. Consequently, in two decisions involving London-seated arbitrations, injunctions were refused, in the first case because the basis for impeaching the arbitration agreement (duress) was considered 'hopeless ${ }^{\prime}$ and in the second because the applicant's delay disentitled it to relief. ${ }^{2}$ In contrast, in the context of multiple proceedings before an English court and an English-seated arbitral tribunal in respect of the same subject matter, there was a greater willingness to restrain arbitrations because of the wasted costs, duplication and risk of inconsistent results that arose from split actions between court and arbitrator. ${ }^{3}$ Hence, courts would often strive to consolidate all proceedings in a single court action in such circumstances. 4

In the case of foreign arbitration proceedings, there was a reluctance to grant injunctive relief due to a concern that such an order would interfere with the supervisory jurisdiction of the court at the seat of arbitration. ${ }^{5}$

\section{GENERAL PRINCIPLES OF ARBITRATION LAW}

Since the enactment of the Arbitration Act 1996 (AA) there have been several English decisions in which anti-arbitration injunctions have been sought. The cases have not always been easy to reconcile, with some judges taking a broad and liberal

1 The Ithaka [1939] Lloyd's Law Report 259 (CA).

2 Compagnie Nouvelle France Navigation SA v Compagnie Navale Afrique du Nord [1966] 1 Lloyd's Law Report 477 (CA).

3 Doleman \& Sons v Ossett Corp [1912] 3 KB 257; Lloyd v Wright [1983] QB 1065.

4 See eg University of Reading $v$ Miller Construction Ltd (1996) 75 BLR 91.

5 See eg Black Clawson International Ltd v Papierwerke Waldhof-Aschaffenburg AG [1981] 2 Lloyd's Rep 446. 
view of the circumstances in which an injunction may be awarded, and others being more restrictive. Many commentators ${ }^{6}$ have suggested that anti-arbitration injunctions should be generally prohibited since they offend fundamental principles of international arbitration law. Specifically, in the case of locally seated arbitrations, a supervisory court's power to intervene in matters of arbitral jurisdiction is limited to three situations. The first is where a claimant commences court proceedings in breach of an arbitration agreement and the defendant applies to the court for a stay or dismissal of the proceedings. The second situation is where an arbitral tribunal makes a determination on jurisdictional matter under its 'competence-competence' powers and the supervisory court reviews that decision. Competence-competence is a principle that exists in all major national arbitration statutes and the UNCITRAL Model Law on International Commercial Arbitration ${ }^{7}$ and confers a power on an arbitral tribunal to determine its own jurisdiction, which includes the capacity to decide the validity, existence, and scope of the arbitration agreement. Indeed, some commentators argue that the arbitral tribunal should be given the first opportunity to decide jurisdictional questions. ${ }^{8}$ The third situation is when an application is made to the supervisory court to set aside a final award because the arbitral tribunal lacked jurisdiction. Any other judicial intervention in matters of arbitral jurisdiction (including an anti-arbitration injunction) should generally not be permitted. ${ }^{9}$

In the case of a foreign seated arbitration the case for judicial abstention in arbitral jurisdiction is even more strongly made by commentators. ${ }^{10}$ Restraining pursuit of a foreign arbitration has traditionally been seen through the lens of comity, in the sense that the court seized owes a duty both to the foreign arbitral tribunal and the foreign supervisory court not to intrude on their territorial jurisdiction. Furthermore, the issuing of an injunction to enjoin the conduct of a foreign arbitration may be regarded as inconsistent with globally applicable international arbitration instruments, such as the New York Convention. ${ }^{11}$ According to this view, the Convention has created a code or framework that states when it is permissible for a court outside the seat of arbitration to pronounce upon an arbitrator's jurisdiction or the validity and existence of the arbitration agreement. Prior to an award being made a court may only determine such questions in the context of an application to stay court proceedings in favour of arbitration under Article II(3) of the Convention. Article II(3) provides that where a matter is the subject of a court proceeding that falls within the

6 See eg S Schwebel, 'Anti-Suit Injunctions in International Arbitration: An Overview' in E Gaillard (ed), Anti-Suit Injunctions in International Arbitration (Juris Publishing Inc 2005) 5, 10; J Lew QC, 'Does National Court Involvement Undermine the International Arbitration Process?' (2009) 24 American University International Law Review 489, 509-511, 536; G Born, International Commercial Arbitration (2nd ed, Wolters Kluwer 2014) 1311-13.

7 Model Law, art 16.

8 S Subramanian, 'Anti-arbitration Injunctions and Their Compatibility with the New York Convention and the Indian Law of Arbitration: Future Directions for Indian Law and Policy' (2018) 34 Arbitration International 185, 189 (emphasis in original); Lew (n 6).

9 Note that under most national arbitration laws there are also court powers to remove arbitrators for misconduct, such as bias and lack of qualifications. However, these grounds of removal do not directly concern matters of arbitral jurisdiction.

10 G Dunning, 'Stop or Go? Injunctions and Arbitration' (2008) 74 Arbitration 254, 257; Born (n 6).

11 Some commentary has suggested that the Convention is also relevant in locally seated arbitrations where one of the parties is foreign: Schwebel (n 6) 11. 
scope of an arbitration agreement, the court must decline jurisdiction and refer the parties to arbitration unless the agreement is invalid, inoperative, or incapable of being performed.

Outside of this principle, a Contracting State to the Convention 'should not interfere with the ability of [another state].... to recognise and enforce arbitration agreements. ${ }^{12}$ No implied or residual power therefore exists for a court to grant a further remedy to review or obstruct the jurisdiction of the tribunal, such as an antiarbitration injunction.

The doctrine of competence-competence, referred to above, is a further principle of international arbitration law that is said to be infringed by injunctions that restrain the conduct of foreign arbitrations. ${ }^{13}$ For a court outside the seat of arbitration to issue an injunction to enjoin the arbitration because, for example, it considers the clause invalid, would deny both the foreign arbitrator and the foreign supervisory court the right to resolve the question. ${ }^{14}$

The weight of authority against the issuing of anti-arbitration injunctions is strong, particularly in foreign seat cases. It must however be balanced against the traditional common law approach in dealing with cross-border jurisdictional disputes, where case management and forum non conveniens principles are used to identify the tribunal that will best serve the interests of justice. ${ }^{15}$ In particular, as was noted in the pre-1996 English cases on anti-arbitration injunctions, common law courts have often sought to avoid fragmentation of disputes between different courts and tribunals and to consolidate related actions in one forum where possible. ${ }^{16}$ The need to retain discretionary controls in jurisdictional matters and do justice in the particular case remains important, even where an arbitration clause is involved. Indeed, where there is evidence of abuse of the arbitral process, the case for court intervention becomes more compelling. Consequently, there is a reluctance to renounce antiarbitration injunctions completely in common law jurisdictions.

The question to be explored in this paper is whether the competing policies above can be reconciled-perhaps with anti-arbitration injunctions retained but only awarded in restricted circumstances.

\section{ENGLISH LEGISLATIVE FRAMEWORK}

The English legislative framework for the grant of anti-arbitration injunctions first needs to be considered. For arbitrations with an English seat the AA is the lex arbitri, that is, the law governing the arbitration procedure. Under the AA there are several provisions relevant to anti-arbitration injunctions. The first is section 1 (c) of the AA, which provides that 'in matters governed by this Part, the court should not intervene except as provided by this Part'. Section 1(c) is similar, but not identical, to Article 5 of the Model Law, which provides that 'in matters governed by this Law, no court

12 Born (n 6) 1312-13.

13 Lew (n 6) 509.

14 F Bachand, 'Anti-suit Injunctions and the Model Law' in E Gaillard (ed), Anti-suit Injunctions in International Arbitration (Juris Publishing Inc 2005) 87, 112.

15 See eg Spiliada Maritime Corp v Cansulex [1987] 1 AC 460.

16 See eg Incitec Ltd v Alkimos Shipping Corp (2004) 138 FCR 496; Donohue v Armco Inc [2002] 1 Lloyd's Rep 425 . 
shall intervene except where so provided in this Law'. In an unreported English case decided soon after the enactment of the AA, it was said that section 1(c) 'provides guidance to the court but does not remove [its] jurisdiction'. ${ }^{17}$ This approach has been consistently adopted in decisions since, with the Court of Appeal ${ }^{18}$ recently confirming that the use of the word 'should' in section 1(c) compared to the more mandatory 'shall' in Article 5, was evidence that a more liberal approach to antiarbitration injunctions was intended by the British legislature. ${ }^{19}$

Other relevant provisions include section 9, which provides for a mandatory stay of court proceedings where the matter falls within the scope of an arbitration agreement and the agreement is not invalid, inoperative or incapable of being performed. Secondly, there is section 30, which is a competence-competence provision (with limited scope for judicial review in section 67) and thirdly, there is section $72(1)$ which provides that 'a person who takes no part in [arbitration] proceedings may question ... (c) what matters have been submitted to arbitration in accordance with the arbitration agreement, by proceedings in the court for a declaration or injunction'. Interestingly, section 72 has been rarely invoked in English decisions, despite its language appearing to support the grant of anti-arbitration injunctions. Relevantly, the Court of Appeal suggested that in arbitrations under the AA, an arbitral tribunal should generally determine its own jurisdiction and so a court should be 'very cautious' before granting relief under section $72 .{ }^{20}$

Apart from section 72, there is no specific provision in the AA that provides for the issuing of anti-arbitration injunctions. Instead English courts, in the cases since 1996, have relied upon section 37 of the Senior Courts Act 1981 (UK) (SCA) which provides: 'the High Court may ... grant an injunction in all cases in which it appears to the court to be just and convenient to do so.'

In the case of injunctions to enjoin foreign arbitrations, the AA is not the lex arbitri and so the above provisions except section 9 do not apply. However, section 37 of the SCA again provides the jurisdictional basis for the ordering of the injunction. It may have been thought that, given the risk of interference with both the foreign arbitral tribunal and the foreign supervisory court, an English court may hesitate more strongly before granting an injunction in this context. The practice of English courts since 1996 does not however bear out this prediction.

An examination will first be made of the cases involving injunctions and locally seated arbitrations and then foreign arbitrations.

\section{ENGLISH SEATED ARBITRATIONS}

It has been accepted in all English judgments after the enactment of the AA in 1996 that the pre-Act power to grant anti-arbitration injunctions continues to exist. The

17 China Petroleum Technology and Development Corp v LG Caltex Gas Co Ltd (unreported, 5 December 2000, Andrew Smith J).

18 Sabbagh $v$ Khoury [2019] EWCA Civ 1219.

19 ibid [66].

20 Fiona Trust \& Holding $v$ Privalov [2007] 2 Lloyds Rep 267 [34].

21 See eg Weissfisch v Julius [2006] EWCA Civ 218 (33); Elektrim SA v Vivendi Universal SA [2007] EWHC 571 (Comm); Claxton Engineering Services Ltd v TXM Olaj- Ex Gazkutato KTF [2011] EWHC 345 (Comm); J Jarvis \& Sons Pty Ltd v Blue Circle Dartford Estates Ltd [2007] EWHC 1262 (TCC). 
broad test adopted by the courts has three elements. The first requirement is that such an order will only be made 'in exceptional circumstances'. Secondly, the applicant must show that (i) the injunction would not cause injustice to the respondent and (ii) the continuance of the arbitration would be oppressive, vexatious or an abuse of process. Thirdly, there must be no undue delay in seeking the relief.

\subsection{Concurrent proceedings}

In two early decisions involving concurrent proceedings between a court and an arbitral tribunal (J Jarvis \& Sons Pty Ltd $v$ Blue Circle Dartford Estates Ltd ${ }^{22}$ ) and two arbitral tribunals (Elektrim $S A v$ Vivendi Universal $S A^{23}$ ) the 'exceptional circumstances' test was applied to refuse an injunction. Both courts relevantly noted that, after the enactment of the AA, the mere existence of multiple proceedings in respect of the same subject matter and parties was insufficient to support an injunction. While such a situation was undesirable and inconvenient and may result in inconsistent outcomes between tribunals, this did not make the arbitration vexatious or oppressive. Indeed, multiple and overlapping proceedings may inevitably be the result of an order for stay of court proceedings in favour of arbitration under section 9 of the AA, where all parties in the court proceedings are not parties to the arbitration agreement or where all claims in the court proceedings do not fall within the jurisdiction of the arbitrators. The pre-1996 authorities in which anti-arbitration injunctions were issued to eliminate concurrent proceedings were therefore no longer applicable.

Consequently, the court's power to grant an anti-arbitration injunction should not exceed its capacity to stay court proceedings. The remedies should operate in parallel which will help to ensure that the award of injunctions is confined to the circumstances expressly provided in the AA and no wider, residual jurisdiction is created.

Further significant factors telling against the award of an injunction in these cases were the existence of delay on the part of the applicant, ${ }^{24}$ the fact that the concurrent proceedings concerned different subject matter ${ }^{25}$ and that the arbitral tribunal had already refused to stay its own proceedings three times. ${ }^{26}$ In respect of the last point, the court in Elektrim noted that it had no power to review or overrule those decisions (outside the limited circumstances in section 30) in advance of an award. Ordering an anti-arbitration injunction would amount to such review and 'give the court a general supervisory power which it has never had'. ${ }^{27}$

The message from the courts in these cases is clear: the supervisory jurisdiction of English courts over local arbitrations is limited and normally confined to the circumstances expressly provided in the AA.

The above approach was also adopted by a court to deny an injunction to enjoin pursuit of a second arbitration brought by the claimant after an award had been 
made against that party on different subject matter in the first arbitration. ${ }^{28}$ The court there emphasized that the second arbitral tribunal could, under its competence-competence powers, deal with any suggestion that the claimant was engaging in 'rearbitration' of issues already decided. This judgment shows welcome faith in the arbitral tribunal to determine the issues of jurisdiction and res judicata under its competence powers. $^{29}$

\subsection{Court determinations on jurisdiction}

So, when is it appropriate for an English court to restrain an English arbitration? The English Court of Appeal in the very recent decision Minister of Finance (Inc) and 1Malaysian Development Berhad (1MDB) v International Petroleum Investment Coy ${ }^{30}$ has suggested that where an arbitral proceeding is used to interfere with, obstruct or undo the rights of a party to set aside an award before the English supervisory court, an injunction may be granted.

In that case, the parties had commenced a London arbitration that was settled by a deed that made provision for a consent award. The deed contained a clause that referred to arbitration 'any dispute arising from or in connection with the [deed]'. The arbitral tribunal issued the consent award after which the claimant brought proceedings in the English court to set aside the award under sections 67 and 68 of the AA, on the basis that the tribunal lacked jurisdiction and the award was procured by fraud. The defendants responded to the court application by commencing a second arbitration, claiming that there had been events of default by the claimant under the settlement deed entitling them to payment. The events of default included the claimant's court challenge to the consent award. The claimant then sought an anti-arbitration injunction to enjoin the second arbitration, which was granted by the Court of Appeal.

The court emphasized that the AA provisions that provided a right to challenge an arbitral award are 'mandatory' and included not merely for the benefit of the parties but the wider public interest. The supervisory court, in adjudicating challenges to an award is 'acting as a branch of the state ... to facilitate the fairness and well-being of a consensual method of dispute resolution'. ${ }^{31}$ Such powers therefore reinforce the rights of the parties and aim to protect the integrity of the court process and the legal system more generally. An injunction was therefore required to prevent the defendant using a second arbitration to suppress judicial review of the award. The arbitration was therefore both an interference with state power and with a party's fundamental statutory right to challenge an award.

The court's judgment is consistent with an earlier Commercial Court decision in Republic of Kazakhstan v Istil Group Inc ${ }^{32}$ where a London arbitral award had been

28 Nomihold Securities Inc v Mobile Telesystems Finance SA [2012] EWHC 130 (Comm).

29 Regrettably, in a later undefended decision on similar facts, a court did not follow this approach and granted an anti-arbitration injunction despite finding that the arbitral tribunal had jurisdiction under its competence-competence powers to resolve such matters; see Injazat Technology Capital Ltd v Najafi [2012] EWHC 4171 (Comm).

30 [2019] EWCA Civ 2080.

31 ibid [43] quoting Mance LJ in Department of Economics, Policy and Development of the City of Moscow $v$ Bankers Trust Co [2005] QB 207 [34]. 
set aside by the English courts on the ground that the tribunal had no jurisdiction because the defendant was not a party to any arbitration clause. The claimant then sought to 'reconvene' the arbitration proceedings, effectively seeking to undo the decision of the supervisory court but was restrained by injunction. The arbitral tribunal had no jurisdiction to resolve the same dispute between the same parties after the supervisory court had held that the arbitration agreement was not binding. To allow an arbitral tribunal to proceed and defy the court's decision would be 'invidious' and clear evidence of vexatious and oppressive conduct by the claimant.

The principle of deference to determinations of the court of supervisory jurisdiction can also be seen in the pre-1996 case Compagnie Europeene de Cereals SAv Tradax Export $S A .^{33}$ Hobhouse $\mathrm{J}$ there said that if a right or liability is in no respect any longer in dispute between the parties having already been decided by the court then the arbitrators ... do not have any jurisdiction in respect of it. To restrain them from purporting to decide it a second time is therefore to restrain an excess of jurisdiction or authority on the part of the arbitrators. ${ }^{34}$ Even Judge Schwebel, a noted anti-arbitration injunction sceptic, recognizes the possibility that an order may be granted where a party has already arbitrated and lost and seeks to undo that result. ${ }^{35}$

So therefore, where an English arbitral tribunal has no jurisdiction over a matter due to a prior decision of the supervisory court, then the court in ordering an antiarbitration injunction is protecting the integrity of its own proceedings and a party from unconscionable litigation. Such a result is entirely consistent with the doctrines of limited judicial intervention in arbitration and the competence of arbitrators to determine their own jurisdiction. All that it is happening here is that priority is given to a prior decision of the supervisory court on the question of arbitral jurisdiction. The logic of Istil and Tradax would also extend to the situation where a court refused a stay of proceedings in favour of arbitration on the ground that the agreement was invalid, but the claimant nevertheless proceeded with the arbitration.

On reflection, the English approach to anti-arbitration injunctions in local seat cases strikes an appropriate balance. While injunctions will not be awarded on general grounds of case management or inconvenience, 'exceptional circumstances' will exist where a party's capacity to seek judicial review of the award before the supervisory court is curtailed or undermined. Such an approach retains fidelity to the provisions of the AA, which limit court intervention in matters of arbitral jurisdiction, and reinforces the status of arbitration agreements.

\section{FOREIGN-SEATED ARBITRATIONS}

The English position with respect to injunctions and foreign-seated arbitrations has been less clear and more contentious, despite the 'exceptional circumstances' test referred to earlier being repeatedly endorsed in this context. The paradox is that antiarbitration injunctions have been issued more frequently in respect of foreign arbitrations than local seat cases, which suggests a wariness towards foreign tribunals and an insufficient regard for the position of the foreign supervisory court. Specifically, 
discretionary forum non conveniens analysis has appeared in several judgments which has led to an increase in injunctions being granted.

\subsection{Concurrent proceedings}

Evidence of a case management approach can be seen in three decisions: Intermet FZCO $v$ Ansol Ltd, ${ }^{36}$ Excalibur Ventures LLC $v$ Texas Keystone Inc ${ }^{37}$ and Golden Ocean Group Ltd $v$ Humpuss Intermoda Transportasi Tbk Ltd. ${ }^{38}$

In Intermet, an injunction was refused in the context of concurrent proceedings between an English court and a foreign arbitral tribunal. The decisive factors were the applicant's delay in seeking the relief and the fact that the proceedings covered distinct issues and were unlikely to produce inconsistent results. Also, the court noted that the defendant had already expended great sums in the arbitration and would obtain an award 'far more quickly' than a court judgment. The court's approach essentially involved comparing the entitlements of the competing forums to adjudicate, like the forum non conveniens test under Spiliada. ${ }^{39}$ In Spiliada, Lord Goff spoke of seeking the 'more appropriate forum' for trial, which is assessed by examining matters such as the location and accessibility of witnesses, the law governing the transaction, and the places of business of the parties. ${ }^{40}$

Excalibur involved English court proceedings and a New York arbitration against four defendants, three of whom claimed not to be a party to the arbitration agreement. The claims in both proceedings involved similar subject matter. An injunction was ordered to restrain conduct of the foreign arbitration despite the court noting that review of arbitral jurisdiction is normally better left to the foreign supervisory court. In substance the court found itself to be a more appropriate forum than the foreign arbitral tribunal to determine the jurisdictional question. Influential factors were that the claimant had commenced both court and arbitral proceedings in respect of the same matter against the same defendant and the court proceedings were well advanced. Consequently, it would be vexatious for the defendants to have to defend two sets of proceedings involving the same issue. Secondly, the defendants had no connection with the country of arbitration and so would suffer prejudice in terms of time and wasted costs if they had to contest jurisdiction there. Thirdly, the defendants had a strong arguable case that they were not parties to the arbitration agreement.

Excalibur is a concerning decision. It is undoubtedly true that a claimant who commences English court proceedings and a foreign arbitration on the same subject matter against the same party should be entitled to little sympathy. Yet, it is not clear why the foreign arbitral tribunal could not have resolved the question of jurisdiction. Although an anti-arbitration injunction has the 'neater' effect of removing one of the competing proceedings, this is only achieved by denying effect to the arbitration clause. 
Furthermore, a forum non conveniens approach not only sits uneasily with the stated requirements of 'exceptional circumstances' and 'vexation or oppression' for anti-arbitration injunctions but it is also inconsistent with the New York Convention's strict approach to court intervention in arbitral jurisdiction. ${ }^{41}$ The drafters of the Convention were civil lawyers whose aim was to limit court involvement, pre-award, to the case where proceedings had been brought in court and a party sought a referral to arbitration. Once it is found that a valid and binding arbitration agreement exists, and the substantive claims fall within its scope, then a stay in favour of arbitration is mandatory under Article II(3). There is no provision for a discretionary weighing of the merits of proceeding in court as opposed to the arbitral tribunal. The matter must be referred to arbitration once a valid and binding arbitration agreement, covering the parties' claims, is identified. Yet, it is precisely this type of analysis which the court in Excalibur seeks to introduce through the medium of the anti-arbitration injunction and if this view is widely accepted, foreign arbitration agreements may become less secure. In effect, an appropriate forum test could make anti-arbitration injunctions routine instead of exceptional. ${ }^{42}$

Further evidence of this balancing approach can be seen in Golden Ocean Group Ltd $v$ Humpuss Intermoda Transportasi Tbk Ltd. ${ }^{43}$ This case concerned an application to restrain a Singapore arbitration on the basis that the injunction applicant was not a party to such an arbitration agreement. Previously, the applicant had commenced a London arbitration against another party $(\mathrm{H})$ and obtained an award to the effect that a valid arbitration agreement existed between them.

The judge identified the 'threshold question' as being whether it was more appropriate for the court to resolve the question of enforceability or validity of the arbitration agreement or to allow the matter to be determined by the foreign arbitral tribunal under the competence-competence doctrine. The issue was framed, similar to Excalibur, in explicitly forum non conveniens terms with the court downplaying the significance of competence-competence, noting that any decision of the tribunal on jurisdiction may be subject to judicial review at various stages. A non-supervisory court was therefore acting consistently with 'the philosophy of arbitration'44 in resolving the question of arbitrability, even outside a stay application.

The court then proceeded to list discretionary factors that may be relevant in deciding whether the court should defer to the arbitrator or resolve the question of arbitral jurisdiction itself. First, if the jurisdiction issue is likely to be resolved by the court at a later stage then this factor favours the court determining it now, to save costs. In contrast, if the matter cannot be decided quickly without a lengthy and

41 A type of 'non-party autonomy' is created: see J Gaffney, 'Non-party Autonomy: Displacing the Negative Effect of the Principle of 'Competence-Competence' in England? A Comment on Excalibur Ventures LLC $v$ Texas Keystone Inc' (2012) 29 Journal of International Arbitration 107, 115-16.

42 Commentators share this view. According to Born, the fact that an arbitration is 'duplicative' of litigation is insufficient for an anti-arbitration injunction: (n 6) 1313. 'The extra cost and inconvenience brought about by parallel proceedings usually is not enough to justify the interference in party and ... arbitral autonomy [caused by an anti-arbitration injunction]': Z Tang, 'Parallel Proceedings and Anti-Arbitration Injunctions' [2012] Journal of Business Law 589, 604. See also Lew (n 6) 510 and D Sutton, J Gill and M Gearing, Russell on Arbitration (24th ed, Sweet and Maxwell 2015) [7.064]. 
costly trial then the arbitral tribunal may be more appropriate. So too, if the matter cannot be confined to a circumscribed area but intrudes on the substantive issues in the dispute. Secondly, if there are related proceedings addressing the issue between the same or other parties the court may resolve the issue to limit the risk of inconsistent judgments. Thirdly, if the relevant issue concerning the arbitration agreement is governed by English law, the case is closely connected with England or general Spiliada factors of convenience favour England (for example, location of evidence and language) then these features also point in favour of court resolution. Finally, the quality of the arbitral tribunal and the foreign supervisory court will also be relevant factors.

On the facts in Golden Ocean, the court felt that the English court should decide the question of the existence of the arbitration agreement, given the risk of inconsistent awards between the London and Singapore tribunals and the fact that English law governed the arbitration agreement. Once this conclusion was reached it was only a short step to awarding an anti-arbitration injunction to enjoin the Singapore arbitration. Such an order was required to prevent both the court and the foreign arbitral tribunal resolving the same question at great duplication and expense.

Golden Ocean evokes a similar response to Excalibur. Once again, the court has prioritized efficiency and tidiness of dispute resolution through use of the forum non conveniens principle over deference to foreign arbitral tribunals and supervisory courts. Interestingly, the judge justified his unwillingness to leave the matter to the foreign arbitrator on the basis that its decision was not final and may be subject to review by the supervisory court at all stages of the process. That observation is certainly true, but it ignores the central issue that an English court owes a duty to both the foreign arbitral tribunal and the supervising court not to interfere in the absence of exceptional circumstances.

The courts in Excalibur and Golden Ocean relied on forum non conveniens principles to support the English court's right to resolve the question of arbitral jurisdiction, rather than the foreign arbitrator. In a later decision, Whitworths Ltd $v$ Synergy Food Ingredients and Processing $B V,{ }^{45}$ the court went even further and granted an injunction restraining pursuit of a Dutch arbitration simply because it was more likely that the parties had entered a London arbitration agreement than a Dutch one. No attempt was even made to justify the English court's right to determine the matter. The court disposed of the competence-competence objection by saying, similar to the view in Golden Ocean, that it was not an absolute principle in that the arbitrator's jurisdiction can be reviewed by the supervising court. Once again, however, this observation does not justify intervention by another court outside the seat. Such courts are expected to show deference to both the foreign arbitral tribunal and the supervisory court on matters of arbitral jurisdiction. The court should have allowed the Dutch arbitral tribunal to determine the jurisdictional question. ${ }^{46}$

After Excalibur and Golden Ocean, it may have been thought that the grant of an anti-arbitration injunction was now based on the principles of forum non conveniens. 
If the English court considered itself better placed to resolve the issue of arbitral jurisdiction than the foreign arbitrator, then it would do so.

\subsection{Prior determination or prior agreement}

The two most recent English cases involving foreign-seated arbitrations, AmTrust Europe Ltd $v$ Trust Risk Group $S p A^{47}$ and especially Sabbagh $v$ Khoury, ${ }^{48}$ appear however to have reversed this trend and returned to a test for anti-arbitration injunctions that stresses their exceptional nature.

In AmTrust, the claimant entered a terms of business agreement with the defendant that contained an English exclusive jurisdiction clause. Later, the parties entered into a framework agreement that provided for Italian arbitration. After a dispute arose between the parties, the defendant commenced arbitration in Italy under the framework agreement and the claimant sued in England on the merits and also sought an anti-arbitration injunction. The English Court of Appeal had found in an earlier hearing that the English courts would have jurisdiction over the defendant in the case based on the exclusive jurisdiction clause and it was this finding which the claimant relied upon in support of the injunction.

The judge refused the injunction, stating that no exceptional circumstances were present. Such circumstances would have existed where an English jurisdiction clause was found to apply and extended to the parties' claims '... either because it was common ground between the parties or because of a previous determination [by a court]. ${ }^{49}$ The problem in AmTrust was that although there was no dispute that the parties had agreed to the English exclusive jurisdiction clause in the terms of business agreement and that the English courts had jurisdiction over the defendant, it had not been determined that the clause applied to the claims in the dispute. Therefore, there was no relevant 'prior determination' to support an injunction. The court also stressed the importance of the principle of competence-competence and the need to respect the role and position of the foreign supervisory court. It was therefore proper that the Italian arbitration tribunal decide the question as to whether the English jurisdiction clause or the Italian arbitration agreement applied to the parties' dispute. If a party was unhappy with the arbitrator's decision, then they could appeal to the Italian court.

The approach in AmTrust is a welcome reaffirmation of the competencecompetence principle and the view that anti-arbitration injunctions are exceptional, not routine orders. Unlike a stay application where the English court's power to review the jurisdiction of a foreign arbitral tribunal is conferred by both statute and the New York Convention, no such express power exists to support anti-arbitration injunctions in international arbitration law. This remedy is a common law invention whose scope must be defined in accordance with international arbitration principles. Such principles require deference to the foreign arbitral tribunal and supervisory court in most cases other than where an English court has already determined, pursuant to an earlier stay application, that the tribunal has no jurisdiction because for 
example the agreement is invalid or does not cover the parties' dispute. Allowing English courts to determine arbitral jurisdiction on a wider basis could lead to an upsurge in the grant of anti-arbitration injunctions.

The most important recent English case on anti-foreign-arbitration injunctions is the decision of the Court of Appeal in Sabbagh $v$ Khoury. ${ }^{50}$ In Sabbagh, the claimant (S) was the daughter and the defendants were the sons of a businessman $(\mathrm{H})$ who had died. $\mathrm{H}$ had created a Lebanese company CCG to operate his business and S's brothers and CCG were claimants in the Lebanese arbitration.

$S$ brought two claims in the English proceedings: an asset misappropriation claim, and a share deprivation claim relating to shares in CCG. In the arbitration the Lebanese claimants sought a declaration as to their entitlement to shares in CCG (the shares claim) and a determination of any moneys owed by CCG (the asset claim). The Lebanese arbitration was commenced under CCG's articles of association. The claimants in the arbitration applied for a stay of the English court proceedings in favour of arbitration under section 9 of the AA and, in 2017, an English court refused a stay, finding that neither the asset misappropriation claim nor the share deprivation claim fell within the scope of the arbitration agreement. In a later judgment, an anti-arbitration injunction was awarded.

The defendants appealed to the Court of Appeal, challenging not only the grant of the injunction but also the findings regarding the scope of the arbitration clause in the 2017 stay judgment. The Court of Appeal upheld the 2017 decision in respect of the asset misappropriation claim but found that the share deprivation claim fell within the terms of the arbitration agreement. In respect of the anti-arbitration injunction application, which was pressed in respect of both claims, the court confirmed that it had jurisdiction under section $37(1)$ of the SCA to grant such relief, even in respect of foreign-seated arbitrations. ${ }^{51}$ Interestingly, the court noted that the New York Convention did not expressly prohibit such orders, ${ }^{52}$ although the likelihood of the predominantly European civil law drafters of the Convention even being aware of the remedy in 1958 seems remote. Next, the court noted that there was nothing in the AA to prohibit such injunctions either since most of its provisions applied only to locally seated arbitrations. ${ }^{53}$ While this comment is true as an empirical observation, it should not mean that injunctions should be easier to obtain in respect of foreign arbitrations.

In respect of the share deprivation claim, the court refused to order an injunction, because the claim, in a 'prior determination' had been found to fall within the jurisdiction of the arbitral tribunal. Since a stay of English court proceedings would have been mandatory in respect of such a claim, no injunction should be granted either. Such a conclusion accorded with the Convention's 'respect and giving effect to arbitration agreements. ${ }^{54}$ The court specifically endorsed and adapted the approach of Andrew Smith J in AmTrust that an injunction would only be granted where there is no room for argument' that an arbitration clause is invalid, non-existent or does not 
cover the relevant claims, either because of a prior agreement between the parties or because of a previous court determination.

The second ground of appeal concerned the assets claim which had been found to fall outside the scope of the foreign arbitration agreement. Consequently, there was a prior determination that the arbitral tribunal had no jurisdiction and so an injunction was granted.

The court in Sabbagh referred to two other cases with approval where prior determinations by courts or agreements between the parties were relied upon in support of the issuing of an injunction. In Claxton Engineering Services Ltd $v$ TXM-Olaj-Ex Gazkutato $K_{T F} F^{55}$ an injunction had been sought to restrain the defendant from continuing an arbitration in Hungary and in an earlier application an English court had refused the defendant's request for a stay. The basis for the rejection was that the arbitration clause was invalid because the parties had instead agreed to refer their disputes to the English courts under an exclusive jurisdiction clause. This finding therefore constituted a 'prior determination' that the clause was invalid.

An example of a case where the parties by 'prior agreement' had rendered an arbitration clause inoperative was Albon v Naza Motor Trading Sdn Bhd. ${ }^{56}$ In Albon, an English court refused a stay in favour of arbitration in Malaysia on the ground that the arbitration clause was likely forged. The defendant then gave an undertaking that it accepted the court's decision on the clause's invalidity. Upon the defendant commencing arbitration proceedings, the claimant obtained an anti-arbitration injunction.

Returning to Sabbagh, the defendant also argued that an injunction should only be granted in such circumstances where the English court was also the 'natural forum' to resolve the dispute. It was noted earlier in Excalibur and Golden Ocean that the courts expressly relied on principles of forum non conveniens and natural forum to determine whether an anti-arbitration injunction should be ordered. The Court of Appeal rejected this approach, which it said reflected the very different context of anti-suit injunctions. The rationale for the latter relief was to prevent interference with the sovereign jurisdiction of other countries' courts, and to respect comity, with the natural forum concept being a means by which this goal was achieved. Antiarbitration injunctions, however, stand in a different category. They do 'not involve an interference with the jurisdiction of a foreign court except in the very indirect way of relieving it of its role as the supervisory court of the arbitration, but that is a role that is entirely dependent on the continuation of the arbitration'. ${ }^{57}$ Hence, the basis of the injunction is the lack of jurisdiction in the arbitral tribunal, either because the arbitration agreement is invalid, non-existent or does not cover the matters in dispute.

An anti-arbitration injunction, therefore, more accurately involves interference with 'the fundamental principle of international arbitration that courts should uphold and therefore not interfere with arbitration agreements'. ${ }^{58}$ As comity and 
interference with foreign courts are lesser features of an anti-arbitration injunction, England does not have to be the natural forum for an injunction to be ordered in respect of claims falling outside a foreign arbitration clause. Hence, for such cases and those, for example, where an arbitration agreement is invalid or non-existent, an injunction may be granted where there is a prior court determination to that effect.

The question that remains is how a court should proceed where the validity or scope of the arbitration agreement has not been the subject of a prior court determination. Here the court suggests that an injunction should normally not be granted. 'Kompetenz-kompetenz is an important principle of international arbitration law whereby the parties agree that the arbitral tribunal may rule on its own jurisdiction'. In such a case, the English court should defer to the tribunal. ${ }^{59}$

Sabbagh is a welcome decision which, when coupled with the Istil case above, effectively unifies the principles for anti-arbitration injunctions in local and foreignseated arbitrations around the concept of prior judicial determination. Where an English court, either pursuant to a stay application, on appeal from a tribunal decision in a competence-competence proceeding or in a challenge to a final award, has determined that an arbitration agreement is invalid, non-existent, or of insufficient scope then an anti-arbitration injunction may be ordered. Alternatively, where the parties have agreed to waive the arbitration clause, then this also engages the court's jurisdiction. Limiting the relief in this way ensures consistency with arbitration legislation and international arbitration instruments and prevents excessive judicial intrusion into arbitral jurisdiction. This approach also acknowledges and respects prior judicial processes in respect of arbitration.

A foreign arbitral tribunal is not simply a competing forum in the Spiliada sense, on the same level as an English court in terms of its entitlement to adjudicate, but a body that has special status and recognition in international arbitration law. If arbitration is to be encouraged as a dispute resolution method in international commerce, then courts need to respect and enforce the rights of arbitrators to resolve questions relating to their own jurisdiction. Such a view is supported by the House of Lords decision in Premium Nafta, ${ }^{60}$ which called for broad and flexible interpretation of arbitration clauses by courts with the aim of making the 'first port of call for jurisdictional issues ... the tribunal'. ${ }^{61}$ A strict approach to anti-arbitration injunctions is therefore required. ${ }^{62}$

59 ibid [111].

60 Premium Nafta Products Limited v Fili Shipping Company Limited [2007] UKHL 40.

61 H Seriki, Injunctive Relief and International Arbitration (Informa Law from Routledge 2014) 120.

62 An alternative view suggests that it is 'in the best interests of the parties and the arbitral process' that 'early determination of issues concerning the jurisdiction of the arbitral tribunal' be achieved through liberal use of the anti-arbitration injunction. Otherwise the parties will expend costs and time on an arbitration that will produce an award that will be ultimately set aside for lack of jurisdiction in any event. See N Poon, 'The Use and Abuse of Anti-Arbitration Injunctions' (2013) 25 Singapore Academy of Law Journal 244 , 265. Such a view, however, places very few restraints on the issue of anti-arbitration injunctions. Raphael suggests that an injunction would be rarely appropriate where the jurisdiction of the arbitrators is not challenged: T Raphael, The Anti-suit Injunction (2nd ed, Oxford University Press 2019) [11.37]. 


\section{INJUNCTIONS AGAINST ARBITRATORS PERSONALLY}

A distinct issue from the cases so far discussed is where an application is made to enjoin an arbitrator personally. At first sight there appears something unseemly about an attempt by a party to injunct another tribunal as opposed to the party bringing the impugned proceedings. Arbitrators are typically neutral players in combat between others and notions of inter-tribunal comity should have substantial weight here. ${ }^{63}$ Also, the fact that there are express grounds under both the AA and the Model Law for removal of arbitrators (for example, for bias) ${ }^{64}$ or for challenging the tribunal's jurisdiction ${ }^{65}$ casts doubt on the availability of injunctions in this context.

In Weissfisch $v$ Julius, ${ }^{66}$ the seat of the arbitration was in Switzerland and one of the claims was that the arbitrator had acted in breach of fiduciary duty. The respondent to the arbitration sought to restrain the arbitral proceeding but the English Court of Appeal refused, finding there to be no exceptional circumstances to justify the order, especially given that the seat was foreign.

It seems difficult to imagine what circumstances would be sufficiently exceptional to justify the grant of such an order.

\section{OTHER COMMON LAW JURISDICTIONS}

The position in other common law jurisdictions is not uniform, although some common features can be identified. First, in the case of locally seated arbitrations there appears a general reluctance to grant relief unless the interests of third parties are involved. It is notable that in all six jurisdictions surveyed (Hong Kong, Singapore, Australia, New Zealand, Malaysia, and Canada) the Model Law has been implemented as the lex arbitri for international arbitrations with local seats. Article 5 of the Model Law, which provides that 'in matters governed by this Law, no court shall intervene except where so provided in this Law' has been found not to be a bar to the grant of an injunction in all cases.

In contrast, in the case of foreign-seated arbitrations, there seems a greater readiness in some cases to employ the remedy on discretionary, convenience grounds with perhaps insufficient concern for the roles of the foreign arbitral tribunal and supervisory court. Fortunately, there is also some evidence of an approach similar to that taken in Sabbagh and IMDB taking root, but so far it is patchy and inconsistent.

\subsection{Locally seated arbitrations}

In two Hong Kong decisions on similar facts, $S A v K B^{67}$ and Lin Ming $v$ Chen Shu Quan, ${ }^{68}$ injunctions to restrain the conduct of arbitrations in Hong Kong were refused. Both cases involved a defendant who brought arbitration proceedings against the claimant, with the claimant then bringing court proceedings against the defendant in respect of the same issues. 
The courts made the following important observations. The first comment concerns Article 5 of the Model Law, which provides that in matters governed by this Law, no court shall intervene except as where provided by this Law'. Some commentators have suggested that this provision excludes any form of judicial assistance and control not expressly provided for in the Model Law. ${ }^{69}$ Such a view would obviously preclude anti-arbitration injunctions in all circumstances, but the Hong Kong courts have rejected this analysis. Article 5 of the Model Law does not oust the court's jurisdiction to issue anti-arbitration injunctions; its effect is to require that such power only be exercised 'sparingly ${ }^{70}$ and in exceptional circumstances. ${ }^{71}$ Of great importance are the principles of autonomy and independence of arbitrators from court intervention. $^{72}$

Secondly, the mere fact of concurrency and multiplicity of proceedings between court and arbitrator is not sufficient to justify an injunction, particularly where the two actions were not brought by the same claimant or where the claimant had caused this situation by subsequently bringing duplicative court proceedings. Thirdly, it was particularly inappropriate to grant an anti-arbitration injunction where the arbitral tribunal itself, exercising its competence-competence powers, had rejected a challenge to its jurisdiction ${ }^{73}$ or where a court had previously issued a stay in favour of arbitration. ${ }^{74}$ In the first case, an injunction would have the appearance of the court overruling the arbitral tribunal (other than according to the express power of judicial review in article 16 of the Model Law) while in the second, an anti-arbitration injunction following a stay would leave the parties with no forum for dispute resolution. ${ }^{75}$ A Singapore court ${ }^{76}$ likewise refused to issue an anti-arbitration injunction after having granted a stay of court proceedings in favour of arbitration.

The Hong Kong cases are consistent with the philosophy of Sabbagh and $1 M D B$ in their narrow approach to anti-arbitration injunctions, respect for the role of arbitral tribunals and rejection of a forum non conveniens analysis in the context of competing proceedings.

An interesting and even more emphatic statement against anti-arbitration injunctions in locally seated arbitrations appears in the New Zealand case, Queenstown Mini Golf Ltd $v$ Brecon Street Partnership Ltd. ${ }^{77}$ Similar to the Hong Kong cases, Queenstown Mini Golf concerned concurrent proceedings in respect of the same subject matter brought by a claimant in court and the defendant in arbitration. The court refused the claimant's request for an injunction, noting that the remedy was excluded under the Model Law. The court endorsed the reasoning in the Carter Holt $\operatorname{case}^{78}$ (discussed below) regarding the effect of article 5 of the Model Law. According to this view, a court has no power to award an anti-arbitration injunction

69 Bachand (n 14) 90-91; Lew (n 6) 509-10.

70 Lin Ming $v$ Chen Shu Quan [2012] HKCFI 328 [53].

$71 S A v K B[2011]$ HKCFI 2029 [83].

72 ibid [87].

73 ibid [111]-[112].

74 Lin Ming $v$ Chen Shu Quan [2012] HKCFI 328.

75 ibid [35].

76 Malini Ventura v Knight Capital Pte Ltd [2015] SGHC 225.

77 [2014] NZHC 1101.

78 Carter Holt Harvey Ltd v Genesis Power Ltd [2006] NZHC 114. 
in any case where the matter is governed by the Model Law. Here the issue was the scope of the arbitration clause, which was a matter that fell squarely and exclusively within the tribunal's competence-competence powers under article 16, in the absence of an application to court to stay proceedings. No power to award an anti-arbitration injunction therefore existed. The fact that there were other matters in dispute between the parties that were not the subject of an arbitration agreement did not disturb this conclusion.

Furthermore, the court also suggested that the question of multiple proceedings itself was a matter that could be resolved by the arbitral tribunal under Article 16. The court accepted that the tribunal has an implied power to stay or adjourn arbitral proceedings where the interests of justice so require. Such a power would include examining the question whether the proceedings in court should be consolidated with the arbitration or tried separately in the court and the arbitral tribunal. Such powers of case management are said to flow from Article 19(2) of the Model Law which gives the tribunal the power 'to conduct the arbitration as it considers appropriate'.

This last observation is significant because it suggests that Articles 16 and 19 may have a wider role to play in resolving disputes involving concurrent jurisdiction between courts and arbitrators. The English cases proceed on the assumption that only a court may consolidate proceedings through use of the anti-arbitration injunction. If, however an arbitral tribunal was considered to have equivalent powers (obviously only in respect of parties to the arbitration agreement) then this arguably limits the need for court injunctive relief. ${ }^{79}$ Indeed, it could be argued that the arbitral power to respond to concurrent proceedings has a more secure basis in international arbitration law and national legislation where it is expressly provided for, whereas antiarbitration injunctions are not. Such an approach would also be consistent with the policy of limited judicial intervention in matters of arbitral jurisdiction.

The Queenstown case is remarkable for its strong support of arbitral independence and autonomy. The intrusion of third parties into a dispute has, in contrast, had the effect of widening the scope for an anti-arbitration injunction according to decisions in New Zealand and Malaysia.

Carter Holt Harvey Ltd $v$ Genesis Power Ltd ${ }^{80}$ concerned a 'co-generation' contract between $C$ and $G$ and a 'turnkey' contract between $G$ and $R$, with the latter containing a New Zealand arbitration clause. $\mathrm{C}$ sued $\mathrm{G}$ for breach of contract and $\mathrm{R}$ for negligence with $\mathrm{R}$ counterclaiming against $\mathrm{C}$. $\mathrm{G}$ then commenced arbitration against $\mathrm{R}$ for breach of the turnkey contract. $\mathrm{R}$ then unsuccessfully requested the arbitral tribunal to stay its proceedings because of the overlap between the arbitration and the court action. $\mathrm{R}$ then sought an anti-arbitration injunction which the court found that it had jurisdiction to grant.

The focus of the court's attention was Article 5 of the Model Law. The court found that the article does not exclude anti-arbitration injunctions in all cases, which

79 For a view that art 16 merely serves 'a prorogation function' of conferring power on an arbitral tribunals to determine its own jurisdiction but does not affect the court's power to issue an anti-arbitration injunction, see Poon (n 62) 280-81. The author does however note that his more liberal approach to antiarbitration injunctions may have the effect of 'watering down' the competence-competence principle, with 'the force of article 16(1) ... curtailed': 286. 
is consistent with the view in Hong Kong. After consulting the legislative history, the court noted that the object of the article was to 'exclude any general or residual powers given to the courts under the domestic system which are not listed in the Model Law. ${ }^{81}$ Furthermore, the list of all instances of permitted court involvement in the Model Law applies 'only to matters governed by this Law'. Therefore, if a matter is not regulated in the Model Law, Article 5 does not exclude court intervention. The court noted that the stay provision in Article 8 brings the issue of regulating concurrent court and arbitral proceedings under the scope of the Model Law but only within the confines of that article. Article 8 is limited to the issue of stay of court proceedings between parties to an arbitration agreement. Because the court proceedings in the present case also involved claims by a non-party to the arbitration clause and so were matters that were not the subject of an arbitration agreement, Article 8 could not apply. Consequently, where concurrent proceedings exist between court and arbitrator and the court action involves claims by a non-party to the arbitration agreement, the matter is not governed by the Model Law and so an anti-arbitration injunction is permissible.

The court is correct to say that Article 5 of the Model Law does not preclude anti-arbitration injunctions in all cases. Yet, the conclusion reached as to the article's scope arguably opens the way for too wide a power for the grant of such injunctions. Jurisdiction to issue an injunction will now exist whenever there are concurrent proceedings involving a third party who is not bound by the arbitration agreement. Presumably, a third party may now have the power to 'destroy' an arbitration agreement by bringing court proceedings against a party to such agreement and then successfully injuncting the arbitration.

As asserted above, both the New York Convention and the Model Law chose to limit the circumstances in which a court may intervene, pre-award, in matters of arbitral jurisdiction to determining (i) a stay application and (ii) an appeal from the tribunal's determination of its own jurisdiction. To say therefore that concurrent jurisdiction is only governed by the Model Law when the parties to the arbitration agreement are involved in a dispute is too narrow a view. An alternative approach would be to ask whether the question of judicial intervention in arbitral jurisdiction generally is regulated by the Model Law. The answer would be positive but limited to the powers referred to in (i) and (ii) above. Accordingly, the capacity to award an anti-arbitration injunction should be consistent with such powers and only awarded where a prior determination of a court or agreement of the parties has concluded that the arbitration agreement is invalid, inoperative or of insufficient scope. This is the Sabbagh principle which, as argued above, strikes an appropriate balance between upholding arbitration agreements and preventing unconscionability. In contrast, restraining conduct of an arbitration simply because third party interests are involved would exceed the court's powers.

The fears about third parties undermining arbitration agreements have been heightened after the recent Malaysian Federal Court decision in Jaya Sudhir Jayaram $v$ Nautical Supreme Sdn Bhd. ${ }^{82}$ There, the court upheld an application by a non-party 
to an arbitration agreement for an injunction to restrain pursuit of a Malaysianseated arbitration.

The case concerned a joint venture $\mathrm{N}$, whose shareholders were Nautical and Azimuth. The shareholders agreement creating the joint venture included a Malaysian arbitration clause. Jaya claimed that he had an agreement with the above parties to invest in $\mathrm{N}$ and requested a portion of the shareholding held by Azimuth in $\mathrm{N}$ be transferred to him, which occurred. After the transfer Nautical denied any agreement with Jaya and commenced arbitration against Azimuth and N, seeking a declaration that the transfer to Jaya was a breach of the shareholders agreement. Jaya was not a party to this agreement and so not a party to the arbitration clause. Jaya commenced a court action against Nautical, Azimuth and N, seeking an order that the shares be transferred to him and an anti-arbitration injunction, which was granted by the Federal Court on appeal.

The fundamental premise of the court's decision was that the provisions of the Arbitration Act 2005 (Malaysia) (the 2005 Act) do not apply to non-parties to an arbitration agreement; see the definition of 'party' in section 2. Consequently, section 8 of the 2005 Act, which reproduces Article 5 of the Model Law, does not operate to preclude a third party seeking an injunction to restrain pursuit of a Malaysian-seated arbitration.

Once Article 5 of the Model Law was put aside, the court adopted a very liberal approach to the grant of anti-arbitration injunctions, based squarely on the principles of case management. 'The primary consideration', according to the court, was to adopt 'what would be the fairest approach to all parties ... [which] must not result in any party suffering a severe disadvantage'. ${ }^{83}$ Notably, the English 'exceptional circumstances' test was rejected on the ground that it was confined to injunction applications brought by parties to the arbitration agreement. ${ }^{84}$ According to the court, litigation should be preferred over arbitration where a non-party's rights are involved, especially where concurrent proceedings and the risk of inconsistent results between tribunals were present. Compared to an arbitration tribunal, a court was the only forum in which all parties could be heard, because its jurisdiction is not solely based on consent. A third party should not have its rights affected by a process in which it could have no input. The contemporary policy of upholding arbitration agreements did not conflict with this.

The court noted that concurrent proceedings between court and arbitrator are now much more likely after the introduction of the mandatory stay procedure in the New York Convention and the Model Law. That observation is certainly true in the sense that these instruments both prioritize the enforcement of arbitration agreements over the avoidance of fragmented dispute resolution. It is highly questionable however whether the remedy of the anti-arbitration injunction should be used to 'cure' multiple proceedings by eliminating arbitration. The drafters of the New York Convention, who set out to create a strict code of the limited circumstances in which a court may pronounce upon matters of arbitral jurisdiction, would likely be unimpressed with such a suggestion. 
While the court acknowledged that the presence of a third party to a dispute cannot prevent a stay in favour of arbitration, it saw no problem in relying on the third party to order an injunction to restrain the arbitration. Consequently, a third party can seemingly use an injunction to unravel an arbitration agreement even where a substantial portion of the dispute falls within the jurisdiction of the arbitral tribunal. This result is a clear endorsement of the power of courts to restrain arbitrators on case management or appropriate forum grounds. ${ }^{85}$

If on the facts of Jaya Sudhir, Jaya had sought to join the arbitration and been rejected by the parties, then the argument for discretionary judicial intervention may have been stronger, but here Jaya simply moved opportunistically to stop an arbitration that may have impacted on its interests. The court's reference to the need to grant an injunction to protect the court's processes also seems misplaced. ${ }^{86}$ In Jaya Sudhir two parties to an arbitration agreement validly exercised their legal rights to refer a dispute to arbitration and a third party then commenced court proceedings that dealt with overlapping issues. It seems far-fetched to say that the legitimate conduct of the two arbitrating parties was an interference with court processes when any duplication was the direct result of the third party's subsequent court action. The anti-arbitration injunction should not have been granted.

\subsection{Foreign-seated arbitrations}

The decisions concerning foreign-seated arbitrations are diverse but reveal several of the themes noted in the English jurisprudence. For example, courts in some decisions have refused to grant anti-arbitration injunctions, principally out of a concern for the foreign arbitral tribunal and its competence-competence powers. ${ }^{87}$

In other decisions courts have granted anti-arbitration injunctions where the parties reached an express or implied agreement that a foreign arbitration clause was inoperative. For example, in the Canadian decision $\mathrm{Li} v \mathrm{Rao},{ }^{88}$ the claimant instituted local court proceedings and arbitration in China against the same defendant in respect of the same subject matter. The claimant subsequently gave an undertaking to the defendant not to take any steps in the arbitration or require the defendant to take any steps until the British Columbian court had determined the defendant's application for summary judgment and the claimant's request for a stay of its own proceedings.

After the claimant announced that it would discontinue the court action and proceed with the arbitration, the defendant sought an anti-arbitration injunction. The order was granted on the basis that the undertaking amounted to a promise by the claimant not to pursue the arbitration in favour of the matter proceeding in the

85 The cases cited by the court at [59], Bina Jati Sdn Bhd v Sum-Projects Sdn Bhd [2002] 2 MLJ 71 and Chase Perdana Bhd v Pekeliling Triangle Sdn Bhd [2007] 7 MLJ 677 in which stays of court proceedings were refused to prevent concurrent proceedings, are clearly not in point as they involved discretionary stay applications under the 1952 legislation, not the mandatory process under the 2005 Act. See Su Tiang Joo, 'A Case of Intervention' 20 February 2020 vantageasia.com/case-intervention-federal-court.

86 ibid [66]-[67].

87 Chan Shu Chun v Right Margin Ltd [2015] HKCFI 947; Frank Jonkman and Sons Ltd v DGT-Volmatic A/ S 2004 ONSC 29287. 
British Columbia court, which rendered the arbitration agreement inoperative. It was, the court said, as if the parties had replaced foreign arbitration with a British Columbia exclusive jurisdiction clause. ${ }^{89}$ This case is reminiscent of Albon and entirely consistent with the approach in Sabbagh.

Another Canadian case, Dent Wizard International Corp v Brazeau, ${ }^{90}$ can arguably be explained on the same basis. Again, a claimant commenced local court and foreign arbitration proceedings against the same defendant in respect of similar issues. Significantly, the foreign arbitration clause was contained in a contract that also contained an Ontario exclusive jurisdiction clause, which suggested inconsistent intentions regarding dispute resolution. Reinforcing this choice of Ontario jurisdiction was the fact that the parties had participated in well advanced, pre-trial processes before the court. The dispute was also closely connected with Ontario.

While the court relied on several discretionary factors in its decision to grant an injunction, it was clearly influenced by the Ontario exclusive jurisdiction clause and the parties' engagement with the Ontario court. Such conduct suggested a strong ambivalence of the parties towards foreign arbitration, almost amounting to a waiver.

In other cases, when granting anti-arbitration injunctions, courts have shown much less regard for the position of the foreign arbitral tribunal and supervisory court.

For example, in Lac d'amiante du Québec Itée (LAQ) v Lac d'amiante du Canada $(L A C)^{91}$ LAQ sued LAC and a third party in the Quebec courts and LAC commenced arbitration proceedings against LAQ in New York. LAQ participated in the arbitration by filing a counterclaim which related to the same issue already submitted to the Quebec court. LAQ unsuccessfully sought to stay its own court proceedings and LAC also was unsuccessful in contesting the jurisdiction of the arbitral tribunal to hear LAQ's counterclaim. LAC then sought an anti-arbitration injunction in respect of the counterclaim, which was granted on the basis that the parties had waived the right to arbitrate this issue through participation in the litigation and the subject matter of the counterclaim fell outside the scope of the arbitration clause. The existence of the third party, who could not be heard in the arbitration, was also a relevant factor.

The result in this case is hard to justify: the evidence of waiver or renunciation of the arbitration clause seems weak and the question of the scope of the clause is something that fell squarely within the competence-competence powers of the arbitral tribunal. Indeed, in this case, the tribunal had already ruled on the very issue which was the subject of the injunction. Any review of the tribunal's order should therefore have been left to the supervisory court in New York. Further, the fact that a third party's rights may be involved in a dispute before an arbitral tribunal is a necessary risk of any contractual dispute process. Since the presence of a third party in a dispute provides no defence to a stay application, neither should it support an injunction. The comments made above in respect of the Carter Holt and Jaya Sudhir cases also apply here. 
The decision of the Federal Court of Australia in Hi-Fert Pty Ltd $v$ United Shipping Adriatic $\mathrm{Inc}^{92}$ is more defensible. That case involved a dispute concerning damaged cargo following sea carriage to Australia. $\mathrm{H}$ sued $\mathrm{U}$ in Australia for the damage and $U$, relying on a London arbitration clause in the bill of lading, referred the dispute to arbitration. The proceedings largely mirrored each other with the parties' positions in the court proceeding and the arbitration reversed. U sought a stay of H's Australian court action and applied to the London arbitrators for a ruling on jurisdiction under section 30 of the English Arbitration Act (the competence-competence provision).

$\mathrm{H}$ sought an anti-arbitration injunction, which was granted. Simply put, the arbitration clause was invalid under Australian overriding mandatory legislation ${ }^{93}$ that required litigation in Australia of any dispute involving a bill of lading relating to a carriage of goods by sea from any place outside Australia to any place in Australia. The court strengthened its conclusion by stating that it was vexatious and oppressive for concurrent proceedings to continue when there is a complete overlap in subject matter and parties. The stay application would also have been rejected because of the invalid arbitration clause.

As discussed earlier, the fact of concurrent proceedings between court and arbitrator by itself is hardly a ground for an anti-arbitration injunction, or else parties would be encouraged to bring court proceedings simply to avoid their obligations to arbitrate. Also, the court can be criticized for ignoring the jurisdictional application before the London arbitrators. Comity and the risk of inconsistent orders should have made the Australian court wait until the arbitrators had ruled on the question. Ultimately, however, what justifies the injunction in Hi-Fert was that the stay application would also have been defeated because the local Australian legislation invalidated the arbitration agreement. While there was no prior court determination to that effect, for example, in a stay application, such a conclusion would almost certainly have been reached had the court resolved the stay matter (which had been placed before it) first.

The fullest and most recent treatment of injunctions in respect of foreign arbitrations in Australia is found in Kraft Foods Group Brands Ltd $v$ Bega Cheese Ltd, ${ }^{94}$ although the judgment has some problematic features.

Kraft concerned the ownership in Australia of certain peanut butter 'trade dress'. Prior to the dispute $\mathrm{K}$ had been selling peanut butter in Australia under a particular trade dress and licensed its rights to $\mathrm{M}$, who then sold its business to $\mathrm{B}$, with $\mathrm{B}$ acquiring M's rights under the licence. Upon $\mathrm{K}$ discovering that $\mathrm{B}$ was selling peanut butter under B's name but with K's trade dress and advertising its product with the dress, $\mathrm{K}$ commenced court proceedings against $\mathrm{B}$ in Australia. $\mathrm{K}$ alleged that $\mathrm{B}$ had engaged in false and misleading advertising in breach of the Australian Consumer Law (ACL). ${ }^{95}$ Soon after, K commenced arbitration proceedings in New York under 
the arbitration clause in the licence alleging breaches of the licence and United States trademark law.

$\mathrm{B}$ then sought an injunction in the Australian court restraining $\mathrm{K}$ from proceeding with the arbitration, which was granted. The court relied on general principles of anti-suit injunctions to the effect that the bringing of multiple proceedings by $\mathrm{K}$ in court and arbitration on closely related issues threatened the integrity of the court's processes due to the risk of inconsistent results. ${ }^{96}$ The court relied on decisions involving jurisdiction clauses where courts had refused to order stays in favour of foreign litigation so as to join and consolidate all matters in the local court. ${ }^{97}$ Such cases however involve discretionary stays and concurrent litigation, and so are not easily transferable to the arbitration context where mandatory stays apply, even where concurrent arbitration and litigation proceedings are on foot.

The court in Kraft also rejected the English 'exceptional circumstances' test for anti-arbitration injunctions. No 'extra caution' was needed for the grant of such an order compared to an anti-suit injunction. ${ }^{98}$ Arguably, however this conclusion takes insufficient account of pro-arbitration instruments such as the New York Convention and the Model Law that substantially reduce the extent to which courts can intervene in matters of arbitral jurisdiction.

The court found that the ownership of the trade dress was central to both the alleged breaches of licence in the arbitration and the claims for false and misleading conduct in the Australian court. The claims overlapped and the risk of inconsistent results was substantial. ${ }^{99}$ Further, $\mathrm{K}$ was the claimant in both proceedings and so was responsible for having created this situation. ${ }^{100} \mathrm{~K}$ however argued that the proceedings were not truly overlapping because the misleading conduct claims under Australian statute could not be pleaded in the New York arbitration because they were outside the scope of the arbitration agreement. The court rejected this argument, finding that the terms of the arbitration clause were wide enough to embrace this claim. ${ }^{101}$

The court's reasoning on the scope of the arbitration clause under Australian law is entirely correct ${ }^{102}$ but the conclusion that $\mathrm{K}$ would nevertheless be able to bring its ACL claim in the proceeding is more questionable. Given that the licence agreement was governed by New York law there was at least some risk that the arbitral tribunal would not admit the Australian statutory claim under New York conflict of laws rules. This very same result occurred in Transfield Philippines Inc v Pacific Hydro $L t d^{103}$ where a Singapore arbitral tribunal refused to apply the ACL where the parties had chosen Philippine law to govern their contract. It is therefore understandable why $\mathrm{K}$ brought the parallel Australian court proceedings, given the perceived danger

[2018] FCA 549 [104].

Incitec Ltd v Alkimos Shipping Corp (2004) 138 FCR 496 cited by the court at [105]-[107].

ibid [100].

ibid [79], [109].

ibid [109].

ibid [96], [109].

See Comandate Marine Corp v Pan Australia Shipping Pty Ltd (2006) 157 FCR 45.

[2006] VSC 175. 
of 'losing' its ACL claim in the foreign arbitration. Hence, $\mathrm{K}$ may not have been engaging in improper double vexation.

The Kraft decision is another example of a court using the anti-arbitration injunction to resolve a dispute involving concurrent proceedings, a tendency that has been criticized in this article. It is true that the claimant in this case brought both the court and the arbitral proceedings, which involved overlapping factual matters, and so was responsible for the multiplicity. The legal issues, however, in each action were distinct and, as argued above, $\mathrm{K}$ had a legitimate concern in initiating the Australian proceeding that the foreign arbitrator would not adjudicate a claim for breach of an Australian statute.

It has been noted that under the New York Convention, an order for stay of proceedings in favour of arbitration must be granted, even where related court proceedings are on foot. There is no longer scope for consolidation of court proceedings based on arguments of convenience or efficiency of dispute resolution. Likewise, with anti-arbitration injunctions, the order should only be issued in exceptional circumstances where a prior court ruling has found the arbitration clause invalid, nonexistent, or of insufficient scope or the parties have agreed to waive arbitration. In that way consistency with, and fidelity to, the Convention and principles of international arbitration law are maintained. The effect of the decision in Kraft however is to place the remedy on a more discretionary and case management basis which may lead to more injunctions being granted in the future and the consequent undermining of arbitration. On balance, the injunction in Kraft should not have been granted.

\subsection{Injunctions against arbitrators personally}

There have been two decisions involving applications for such injunctions, which were refused in both cases, largely due to the operation of Article 5 of the Model Law. In Mitsui Engineering \& Shipbuilding Co Ltd $v$ Easton Graham Rush, ${ }^{104}$ a party (M) to a Singapore-seated arbitration challenged the arbitrator on the ground that, in an interim award, he had dealt with matters beyond his jurisdiction and prejudged other issues. $M$ sought an injunction restraining the arbitrator personally, but the request was refused, with the Singapore court relying on Article 5 of the Model Law. $M$ was seeking to challenge the appointment of the arbitrator, which was a matter governed by Articles 12 and 13 of the Model Law and possibly also contest the tribunal's jurisdiction, which was dealt with by Article 16. In neither of those situations was an anti-arbitration injunction made available under the Model Law and so, in accordance with Article 5, the court had no jurisdiction to grant the relief. Such an approach is reminiscent of the Carter Holt and Queenstown Mini Golf cases above in its suggestion that where an issue is expressly governed by the Model Law, with a remedy provided, Article 5 precludes an anti-arbitration injunction.

The Australian decision teleMates Pty Ltd $v$ Standard SoftTel Solutions Pvt Ltd ${ }^{105}$ is very similar in approach and result. After a dispute arose between the parties, the defendant requested the arbitral institution to appoint an arbitrator under its rules whom the claimant then objected to before the tribunal. The arbitrator rejected the 
challenge, claiming that he had been properly appointed and had jurisdiction to determine the dispute. The claimant then sought a declaration that the arbitrator had not been validly appointed and an injunction restraining the arbitrator.

The court rejected the request for an injunction, finding that the arbitrator had given a ruling as to his jurisdiction under Article 16 of the Model Law, which the claimant could have appealed to the court under Article 16(3). An anti-arbitration injunction was again precluded by Article 5 since Article 16 was the exclusive pathway for a party to review the tribunal's jurisdiction during the pendency of the arbitration. The court also felt that this conclusion was consistent with the underlying policies of the Australian international arbitration legislation, which were that 'disputes which the parties have submitted to arbitration should be speedily resolved and intervention of the court ... minimised'. ${ }^{106}$

Both these cases involved locally seated arbitrations where Article 5 had direct application. It would have been interesting to see how courts would address the Weissfisch situation, where the injunction was sought against a foreign seated arbitrator.

\section{CONCLUSION}

An anti-arbitration injunction can evoke strong reactions. Arbitration purists see it as an interloper that interferes in the jurisdiction of arbitral tribunals and causes uncertainty and instability in the arbitral process. They also rightly point out that few national arbitration statutes and no international arbitration instruments expressly permit such relief. The independence and autonomy of arbitrators on matters of jurisdiction is therefore a principle that must be safeguarded. Yet courts, particularly in common law countries, also consider that they have a duty to protect parties from unconscionable dispute resolution outcomes-including where arbitration is involved. Courts further have a concern to preserve their own processes such as where an order has been made that invalidates an arbitration agreement, which a party then seeks to undermine through pursuing arbitration. An attempt to use arbitration to prevent a party from having a final award reviewed by the supervisory court for lack of jurisdiction is another example. In such cases, an injunction is justified. Antiarbitration injunctions therefore have a role in protecting the interests of parties and maintaining a symbiotic relationship between courts and arbitrators in exceptional cases. Since such a relationship is integral to the success of arbitration, antiarbitration injunctions should continue to play a discrete, but limited role. 


\section{University Library}

\section{- M M I N E R VA A gateway to Melbourne's research publications}

Minerva Access is the Institutional Repository of The University of Melbourne

Author/s:

Garnett, R

Title:

Anti-arbitration Injunctions: Walking the Tightrope

Date:

2020

Citation:

Garnett, R. (2020). Anti-arbitration Injunctions: Walking the Tightrope. Arbitration International, 36 (3), pp.347-372. https://doi.org/10.1093/arbint/aiaa019.

Persistent Link:

http://hdl.handle.net/11343/258846 